\title{
Concern raised over US plan for A-bomb survivor studies
}

Tokyo. Japanese and US researchers working for a foundation established nearly 50 years ago to study the effects of radiation on atomic bomb survivors are worried that a plan by the US Department of Energy (DoE) to change the management structure of the programme will jeopardize the autonomy of the foundation and put a further squeeze on its budget.

The Radiation Effects Research Foundation (RERF) in Hiroshima, and its predecessor the Atomic Bomb Casualty Commission have, since 1947, been studying under the management of the US National Academy of Sciences (NAS) the effects on survivors of the atomic bombs dropped on Hiroshima and Nagasaki.

The results of the study have been widely used in setting international standards for safe doses of radiation in the nuclear power industry, and the expertise developed by the foundation has been called on in other circumstances, such as the Chernobyl accident.

In January, the DoE dismayed RERF officials by saying that it wants to transfer the management of the programme from the academy to a US university to encourage radiation research in US universities as a whole. Columbia University in New York is a prime candidate for the job, but the department plans to ask for bids from other contractors. NAS, however, will not be allowed to participate.

Despite assurances from DoE officials that the new contractor's relationship with RERF will be unchanged from that with NAS, officials at the foundation foresee several dramatic changes in the reorganization.

First, under a proposal already prepared by Columbia University, the university would not only play a management role and recruit staff but would also supervise the scientific content of the programme. In particular, it plans to create a computer centre parallel to that of RERF, to share RERF data and collaborate in research. Futhermore, the university would carry out assessments for DoE on the foundation's activities, for example comparing the value of atomic bomb studies to that of other types of research in radiation biology.

Itsuzo Shigematsu, the chairman of the foundation, says that there are potential conflicts of interest in the many roles suggested by Columbia. He and other RERF officials are concerned that, in the process, the neutrality of RERF may be lost.

"The A-bomb survivors and local governments of Hiroshima and Nagasaki have always been staunch advocates of the objectivity of studies at RERF," says Shigematsu. "From the very beginning, the reputation of NAS management for non-governmental neutrality and scientific excellence became a symbol of the US determination to avoid real or apparent interference and to maximize the value of studies." He says that the NAS provides a "crucial buffer" between RERF and the US government.

Such concern is shared by many Japanese researchers involved in radiation research. Hiromichi Matsudaira, president of the Research Development Corporation of Japan and former director of the National

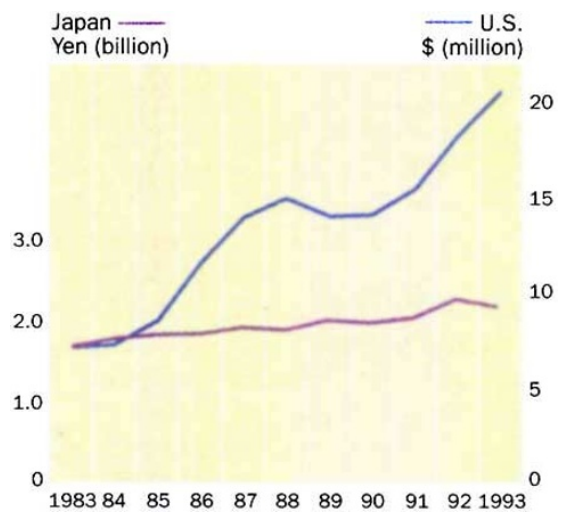

Despite equal contributions in yen, the US budget for RERF in dollars has escalated.

Institute of Radiological Sciences, says there is "no way" the DoE's plan can provide the scientific independence and autonomy of RERF which is "vital" for maintaining radiation protection standards and understanding the long-term effects of radiation.

Shigematsu says the DoE has never explicitly said why it wants to change the management arrangements. He and US scientists at RERF fear that the department's goal is to gain tighter control of the foundation and trim its budget, already being squeezed by the rising value of the yen.

Since it was set up in 1975 , RERF has been funded $50: 50$ by the United States and Japan under an intergovernmental agreement. But over the past ten years, the value of the yen has more than doubled relative to the dollar. Thus, although the foundation's budget in yen has risen very little, the US contribution in dollar terms has tripled to \$23 million in 1994.

Under the resulting squeeze, the foundation has made severe cuts to hold down costs. The number of staff has dropped from 503 in 1983 to 375 , while the number of US researchers has been cut from 22 to 11 .

DoE officials say that they want to stimulate a declining interest in research on radiation in US universities by encouraging young researchers to enter this field. Both US and Japanese researchers at RERF fear that this may be at the expense of US researchers in Hiroshima.

David Swinbanks

\section{House passes bill on cost analysis of new regulations}

Washington. The US House of Representatives has approved a risk assessment and cost-benefit analysis act that would require formal risk assessment before federal agencies introduce any new regulation - an issue close to the heart of its new Republican majority.

Critics of the proposed legislation, including both the Clinton administration and the environmental movement, claim that the process of assessing risks on factors such as cancer risks suggested requires quantitative data in a form science is unable to provide (see Nature 373, 180; 1995).

But despite early talk of a compromise, no amendments were approved on the floor of the House during a debate last week, and the bill was passed virtually unchanged from a proposal published in January.

In particular, Republicans defeated a Democrat bid to prevent industries affected by a new regulation from being allowed to sit on the scientific peer-review panel considering that regulation. Amendments to prevent the peer-review process being challenged in court also failed to win support, causing Tim Roemer (Democrat, Indiana) to brand the proposal "the full employment bill for lawyers and lobbyists".

The fate of the measure now rests with the Senate. Its majority leader Robert Dole (Republican, Kansas) is a strong supporter of regulatory reform of the type proposed by the House. But John Chafee (Republican, Rhode Island), chairman of the Environment and Public Works Committee, believes the proposal would be a setback to efforts to protect the natural environment.

Colin Macilwain

\section{Blood warning 'urgent' says Canadian judge}

Quebec. The head of a public inquiry into Canada's blood supply system has called on hospitals to warn 3.5 million people who received blood transfusions in the late 1970s that they may be at risk of contracting not only HIV but also hepatitis C.

In an interim report, which recommends sweeping changes in the way that blood is collected and used, Mr Justice Horace Krever said that neither public health authorities nor the Canadian Red Cross Society had adequately informed transfusion recipients about the risks of testing.

He proposed that mandatory informed consent should be obtained from all potential transfusion recipients, except in emergencies, and that more use should be made of alternatives, such as autologous blood donations.

David Spurgeon 